\title{
An overview of how rubisco and carbohydrate metabolism may be regulated at elevated atmospheric $\left[\mathrm{CO}_{2}\right]$ and temperature
}

\author{
George Bowes \\ Department of Botany, 220 Bartram Hall, University of Florida, Gainesville, FL 32611, USA, \\ e-mail: bowes@nervm.nerdc.ufl.edu \\ Joseph C.V. Vu \\ USDA-ARS and Agronomy Department, University of Florida, USA \\ Mian W. Hussain \\ Department of Botany, University of Florida, USA \\ Arja H. Pennanen \\ Department of Plant Production, University of Helsinki, Finland \\ L. Hartwell Allen, Jr. \\ USDA-ARS and Agronomy Department, University of Florida, USA
}

\begin{abstract}
Although atmospheric $\mathrm{CO}_{2}$ concentration $\left(\left[\mathrm{CO}_{2}\right]\right)$ has been up to 16 -fold higher than at present, the past several million years have seen atypically low values. Thus, modern-day plants are adapted to cope with a low $\left[\mathrm{CO}_{2}\right] /\left[\mathrm{O}_{2}\right]$ ratio. The present $\left[\mathrm{CO}_{2}\right]$ does not saturate $\mathrm{C}_{3}$ photosynthesis, so its doubling produces an "efficiency effect", but it is not always fully realized. Acclimation to high $\left[\mathrm{CO}_{2}\right]$ during growth can down-regulate photosynthesis, presumably to optimize carbon acquisition and utilization. A primary factor in acclimation is a reduction in rubisco. Two crops, rice and soybean, were used to study this phenomenon. Rice photosynthesis and growth peaked at $500 \mu \mathrm{mol} \mathrm{mol}^{-1}$, whereas soybean responded up to $990 \mu \mathrm{mol} \mathrm{mol}^{-1}$. Rubisco concentration declined under $\mathrm{CO}_{2}$-enrichment and increasing temperatures, more so in rice than soybean. The rubisco $\mathrm{k}_{\text {cat }}$ of rice was unaffected by growth $\left[\mathrm{CO}_{2}\right]$ or temperature, but that from soybean was increased by both. In rice the capacity to handle carbohydrate, as measured by sucrose phosphate synthase activity was up-regulated by $\mathrm{CO}_{2}$-enrichment, but not by temperature. Leaf carbohydrates were increased by $\left[\mathrm{CO}_{2}\right]$, but decreased by higher temperatures, starch more so than sucrose. Even though $\mathrm{C}_{3}$ species differ in response to $\left[\mathrm{CO}_{2}\right]$ and temperature, $\mathrm{CO}_{2}$-enrichment can moderate adverse effects of temperature extremes.
\end{abstract}

Key words: acclimation, ribulose bisphosphate carboxylase-oxygenase, rice, soybean, sucrose phosphate synthase, starch, Q-enzyme 


\section{AGRICULTURAL AND FOOD SCIENCE IN FINLAND}

Bowes, G. et al.: Metabolic regulation under high $\mathrm{CO}_{2}$ and temperature

\section{Atmospheric $\left[\mathrm{CO}_{2}\right]$ : past, present, and future}

Predicting the future is an inexact science, but various scenarios forecast an atmospheric $\mathrm{CO}_{2}$ concentration $\left(\left[\mathrm{CO}_{2}\right]\right)$ of between 575 and $900 \mu \mathrm{mol} \mathrm{mol}^{-1}$ by the year 2100 (King et al. 1992). The consequences of this rise in atmospheric $\left[\mathrm{CO}_{2}\right]$ will not be distributed equally around the globe. The photosynthetic activity of terrestrial ecosystems in northern latitudes is a major component moderating the rise in atmospheric $\mathrm{CO}_{2}$ by sequestering a substantial proportion of the carbon from anthropogenic sources (Takahashi et al. 1992). Thus, as the $\left[\mathrm{CO}_{2}\right]$ continues to rise, the responses of northern ecosystems and agroecosystems could well have important feedback effects that impact the global rate of increase.

Because $\mathrm{CO}_{2}$ is a greenhouse gas its increase is expected to cause global warming, and influence climatic patterns. The current Holocene interglacial period is characterized by a stable climate (Thomson 1993). However, climate can oscillate rapidly, and in the previous interglacial period changes on the order of $10^{\circ} \mathrm{C}$ apparently occurred within a few decades (Dansgaard et al. 1993). Such rapid and extreme temperature fluctuations would have more impact on photosynthesis and growth, even to the point of species survival, than a doubling in atmospheric $\mathrm{CO}_{2}$. An increase of greenhouse gases equivalent to a doubling of $\left[\mathrm{CO}_{2}\right]$ is predicted to lead to a global mean temperature rise of between 1.5 and $4.5^{\circ} \mathrm{C}$ and an increase in average precipitation. However, at regional levels the magnitude of the changes is uncertain (Carter 1996). These climate changes, in addition to higher $\left[\mathrm{CO}_{2}\right]$, will also affect photosynthesis, and the situation is further complicated by interactive effects of the environmental parameters.

$\mathrm{High}\left[\mathrm{CO}_{2}\right]$ and temperature are not new phenomena for the planet. Atmospheric $\left[\mathrm{CO}_{2}\right]$ has apparently fluctuated by more than 20 -fold over geologic time. Mean global temperatures have also fluctuated in some correspondence with changes in $\left[\mathrm{CO}_{2}\right]$. When terrestrial plants first appeared atmospheric $\left[\mathrm{CO}_{2}\right]$ may have been as high as 4000 to $6000 \mu \mathrm{mol} \mathrm{mol}^{-1}$, but the past 400 million years has seen an overall decline (Böger 1980, Budyko et al. 1987, Yapp and Poths 1992, Berner 1993). The rise of vascular plants and their attendant photosynthesis was a major factor in this decline. The past several million years have seen atypically low atmospheric $\left[\mathrm{CO}_{2}\right]$ (Post et al. 1990). As a consequence, many modern-day plants, including crop species, tend to be adapted to a low $\left[\mathrm{CO}_{2}\right] /\left[\mathrm{O}_{2}\right]$ ratio (Badger 1992), but they now have to cope with an atmospheric $\left[\mathrm{CO}_{2}\right]$ that has almost doubled since the last glacial maximum. Plants of the 21 st century will encounter even higher $\left[\mathrm{CO}_{2}\right]$, and likely higher temperature regimes. Furthermore, in northern latitudes changing climatic patterns could extend the season for photosynthetic activity. The degree to which temperate species will respond to these potentially positive inputs will partially depend on their ability to acclimate to the shift in resources, especially a rise in the C:N ratio. In the long-term view it will be influenced by the capacity of a species for genotypic adaptation, or in the case of crop plants, human ingenuity with molecular or classical breeding techniques.

\section{Acclimation to elevated $\left[\mathrm{CO}_{2}\right]$}

The photosynthesis of some $95 \%$ of species $\left(\mathrm{C}_{3}\right)$, which includes virtually all crop and forest species of northern latitudes, is not saturated by the present $\left[\mathrm{CO}_{2}\right]$. Thus in short-term experiments a doubling of $\left[\mathrm{CO}_{2}\right]$ increases the net photosynthetic assimilation rate by $50 \%$; reduces photorespiration, dark respiration, and stomatal conductance; and enhances quantum and water use efficiency, the $\mathrm{C}: \mathrm{N}$ ratio, and modulates growth (Bowes 1993, Woodrow 1994). Thus $\mathrm{CO}_{2}$ enrichment has an "efficiency effect", and in this respect it differs from fertilization responses that occur with other nutrients, such as $\mathrm{N}$ and $\mathrm{P}$.

Table 1 shows the light-saturated, photosynthetic rates for leaves of $\mathrm{CO}_{2}$-enriched rice 
Vol. 5 (1996): 261-270.

Table 1. Photosynthetic rate, rubisco protein concentration, catalytic turnover, and activation in leaves of rice and soybean grown season-long, with natural sunlight and three different day/night temperature and two $\left[\mathrm{CO}_{2}\right]$ regimes. Measurements were made when solar photon irradiance exceeded $1200 \mu \mathrm{mol} \mathrm{m}^{-2} \mathrm{~s}^{-1}$.

\begin{tabular}{|c|c|c|c|c|c|c|}
\hline & \multicolumn{2}{|c|}{ Growth Conditions } & \multirow{2}{*}{$\begin{array}{l}\text { Photosyn- } \\
\text { thetic Rate } \\
(\mu \mathrm{mol} \mathrm{CO} \\
\left.\mathrm{m}^{-2} \mathrm{~s}^{-1}\right)\end{array}$} & \multirow{2}{*}{$\begin{array}{l}\text { Rubisco } \\
\text { Content } \\
\left(\mathrm{mg} \mathrm{g}^{-1}\right. \\
\text { fresh wt) }\end{array}$} & \multirow{2}{*}{$\begin{array}{c}\mathrm{K}_{\text {cat }} \\
\left(\mathrm{mol} \mathrm{CO}_{2}\right. \\
\left.\mathrm{mol}^{-1} \mathrm{~s}^{-1}\right)^{2}\end{array}$} & \multirow{2}{*}{$\begin{array}{c}\text { Activation } \\
(\%)\end{array}$} \\
\hline & $\begin{array}{c}\text { Temperature } \\
\left({ }^{\circ} \mathrm{C}\right)\end{array}$ & $\begin{array}{c}{\left[\mathrm{CO}_{2}\right]} \\
\left(\mu \mathrm{mol} \mathrm{mol}^{-1}\right)\end{array}$ & & & & \\
\hline \multicolumn{7}{|l|}{ Rice } \\
\hline & $32 / 23$ & 330 & 19.3 & 16.4 & 13.0 & 91 \\
\hline & & 660 & 31.8 & 13.0 & 13.6 & 80 \\
\hline & $35 / 26$ & 330 & 21.2 & 15.7 & 14.2 & 87 \\
\hline & & 660 & 32.6 & 12.3 & 13.9 & 85 \\
\hline & $38 / 29$ & 330 & 16.0 & 12.7 & 13.2 & 79 \\
\hline & & 660 & 26.6 & 11.5 & 13.5 & 68 \\
\hline \multicolumn{7}{|c|}{ Soybean } \\
\hline & $32 / 22$ & 350 & 27.5 & 15.5 & 15.6 & 97 \\
\hline & & 700 & 40.9 & 14.2 & 16.8 & 83 \\
\hline & $36 / 26$ & 350 & 23.5 & 14.5 & 16.8 & 86 \\
\hline & & 700 & 39.8 & 13.1 & 18.1 & 78 \\
\hline & $40 / 30$ & 350 & 17.1 & 12.8 & 19.1 & 74 \\
\hline & & 700 & 33.3 & 11.3 & 20.1 & 71 \\
\hline
\end{tabular}

(Oryza sativa L. cv. IR-72) and soybean (Glycine $\max$ L. Merr. cv. Bragg). The plants were grown season-long in natural sunlight under similar controlled conditions at near-ambient and twice-ambient atmospheric $\left[\mathrm{CO}_{2}\right]$, and three different day/night temperatures. The rates were measured on attached, fully-expanded leaves with a LI-COR 6200 system at the growth $\left[\mathrm{CO}_{2}\right]$ and temperature. Measurements were made 90 days after planting for rice and 60 days for soybean at the growth $\left[\mathrm{CO}_{2}\right]$. At a growth temperature of $32^{\circ} \mathrm{C}$, rice and soybean leaf photosynthetic rates were enhanced 65 and $49 \%$, respectively, by doubling the $\left[\mathrm{CO}_{2}\right]$. Thus for both species a positive effect on photosynthesis of the elevated $\left[\mathrm{CO}_{2}\right]$ was maintained. Previous data for these two species showed that the $\mathrm{CO}_{2}$ response for rice photosynthesis, biomass, and yield

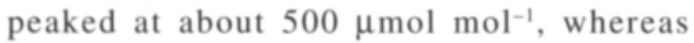
the soybean responded up to at least $990 \mu \mathrm{mol}$ mol $^{-1}$ (Baker et al. 1989, 1990, Campbell et al. 1990)

However, "efficiency effects" such as these in rice and soybean are not necessarily retained by all $\mathrm{C}_{3}$ species in long-term $\mathrm{CO}_{2}$-enrichment experiments. Acclimation can cause down-regulation in photosynthesis, as measured by changes in the response of assimilation rate to intercellular $\left[\mathrm{CO}_{2}\right]\left(\mathrm{A} / \mathrm{C}_{\mathrm{i}}\right.$ curve $)$. Presumably this optimizes carbon acquisition with its utilization in plants that are more adapted to low $\left[\mathrm{CO}_{2}\right]$ conditions.

Acclimation involves various aspects of metabolism, but a major site is ribulose bisphosphate carboxylase-oxygenase (rubisco). This enzyme initiates both the photosynthetic carbon reduction (PCR) cycle, and the photorespiratory carbon oxidation (PCO) cycle, and is a major component regulating $\mathrm{CO}_{2}$ assimilation in $\mathrm{C}_{3}$ species. Control analyses show that at high irradiance the flux control coefficients for rubisco can be as high as 0.8 to 1.0 , where 1.0 indicates it alone is the limiting factor (Stitt and Schulze 1994, Woodrow 1994), though under most conditions, control is shared with other photosynthetic processes.

The kinetics of rubisco have been used to model A/C $\mathrm{C}_{\mathrm{i}}$ curves (Farquhar et al. 1980, Long et al. 1993, Sage 1994). The initial, linear phase of the $\mathrm{A} / \mathrm{C}_{\mathrm{i}}$ curve is a measure of carboxylation 


\section{AGRICULTURAL AND FOOD SCIENCE IN FINLAND}

Bowes, G. et al.: Metabolic regulation under high $\mathrm{CO}_{2}$ and temperature

efficiency, because photosynthesis is limited by the amount of active rubisco. This phase is followed at higher $\left[\mathrm{CO}_{2}\right]$ by an inflection above which A rises more gradually, and is limited by the rate at which RuBP can be regenerated by the PCR cycle. Regeneration of RuBP is linked to the rate of non-cyclic electron transport, which provides ATP for the PCR cycle, and to PCR cycle enzyme activities which convert triose phosphates to RuBP. In the RuBP-limited phase, an increase in $\left[\mathrm{CO}_{2}\right]$ may still increase $\mathrm{A}$ because photorespiration is reduced, and a greater proportion of RuBP is used for carboxylation, instead of oxygenation. Under some conditions, $\mathrm{RuBP}$ regeneration is limited by inorganic phosphate $\left(\mathrm{P}_{\mathrm{i}}\right)$, which depends on the rate at which $\mathrm{P}_{\mathrm{i}}$ in triose phosphates is recycled to the chloroplast (Sharkey and Vanderveer 1989, Socias et al. 1993).

During photosynthesis, $\mathrm{C}_{3}$ leaves maintain $\mathrm{C}_{\mathrm{i}}$ at close to the inflection point, such that rubisco and RuBP-regeneration capacity are co-limiting (Stitt 1991, Long et al. 1993, Sage 1994). A doubling in $\left[\mathrm{CO}_{2}\right]$ reduces stomatal limitations because $\mathrm{C}_{\mathrm{i}}$ rises from about 245 to $490 \mu \mathrm{mol} \mathrm{mol}^{-1}$ $\mathrm{CO}_{2}$. The rise in $\mathrm{C}_{\mathrm{i}}$ causes the initial $50 \%$ increase in photosynthesis that is often reported, and moves photosynthesis into the RuBP-limited region of the $\mathrm{A} / \mathrm{C}_{\mathrm{i}}$ curve (Stitt 1991, Woodrow 1994).

During long-term enrichment (weeks), acclimation may occur in the $\mathrm{A} / \mathrm{C}_{\mathrm{i}}$ curve, with changes in the initial slope and/or RuBP-limited region. The underlying causes of acclimation in the A/ $\mathrm{C}_{\mathrm{i}}$ curve are only partially resolved. Potentially it could be a stress response, indicating physiological dysfunction in plants that over millennia have adapted to low $\left[\mathrm{CO}_{2}\right]$. Or, it may be an optimization process as resources change. In some species or conditions, elevated $\mathrm{CO}_{2}$ produces substantial carbohydrate accumulation within the leaves. The leaf morphology can be deformed; massive starch granules can distort chloroplasts, and possibly disrupt function by distending the thylakoid membranes and imposing constraints on the diffusion of gases or metabolites (Bowes 1991, Stitt 1991, Sage 1994).
In most instances down-regulation of $\mathrm{CO}_{2}$ assimilation probably reflects a restricted capacity to handle the extra carbon, because other environmental resources are insufficient, or the plant has inherent metabolic limitations. According to this view, acclimation is an optimization process that reallocates resources from non-limiting components, such as carbon acquisition, into limiting components such as electron transport, and carbohydrate handling (Bowes 1991, Sage 1994). The availability of $N$ would be a primary factor, because $\mathrm{CO}_{2}$ enrichment increases the C:N ratio of plants (Conroy and Hocking 1993, Pettersson and McDonald 1994).

\section{Rubisco responses to elevated $\left[\mathrm{CO}_{2}\right]$}

Although various biochemical components are involved in acclimation, rubisco has a leading role, due to the fact that this enzyme is both the primary regulatory site for $\mathrm{CO}_{2}$ fixation and a major repository of leaf $\mathrm{N}$. There are reports for a number of species of reduced rubisco activity at elevated $\mathrm{CO}_{2}$ (Spencer and Bowes 1986, Sage et al. 1989, Besford et al. 1990, Rowland- Bamford et al. 1991, Tissue et al. 1993). A decrease in rubisco activity may be caused by a reduction in rubisco protein concentration, which is consistent with the hypothesis that $\mathrm{N}$ is being reallocated. We found the rubisco protein of rice declined linearly with increasing $\left[\mathrm{CO}_{2}\right]$, dropping by as much as $60 \%$ (Rowland-Bamford et al. 1991). Rubisco protein may still decline with seemingly adequate $\mathrm{N}$ supplies (Sage et al. 1989, Rowland-Bamford et al. 1991, Conroy and Hocking 1993), possibly because the C:N ratio during growth is unbalanced. Some species show little or no decline in rubisco concentration (Campbell et al. 1988, 1990, Sage et al. 1989, Socias et al. 1993, Sage 1994). In this regard, our studies with rice and soybean grown under similar conditions indicate that rice seems more 
Vol. 5 (1996): 261-270.

susceptible to down-regulation of rubisco protein than soybean, and this is also true for the A/ C $_{\mathrm{i}}$ curve (Campbell et al. 1988, Rowland- Bamford et al. 1991).

In some situations the reduction in rubisco activity is due to a lower activation state (Campbell et al. 1988, Sage et al. 1989, Yelle et al. 1989, Rowland-Bamford et al. 1991, Socias et al. 1993, Tissue et al. 1993). Enrichment does not change the apparent $\mathrm{K}_{\mathrm{m}}\left(\mathrm{CO}_{2}\right)$ of rubisco (Bowes 1991, Rowland-Bamford et al. 1991).

Table 1 shows several parameters for rubisco extracted from rice and soybean leaves rapidly frozen in liquid $\mathrm{N}_{2}$ around midday, 60 and 53 days after planting, respectively. Rubisco was extracted, and assayed at $30^{\circ} \mathrm{C}$, as described previously (Vu et al. 1987); while rubisco protein concentration was measured using the radioimmune procedure (Vu and Yelenosky 1988).

Rice grown at the two lower temperatures showed about a $20 \%$ decrease in rubisco protein concentration under the double- $\mathrm{CO}_{2}$ treatment (Table 1). Soybean, however, exhibited only about a $10 \%$ reduction. The catalytic turnover rate $\left(\mathrm{K}_{\mathrm{cat}}\right)$ of rice rubisco was unaffected by the high $\left[\mathrm{CO}_{2}\right]$ treatment; whereas unexpectedly, that of soybean showed a small but consistent increase (Table 1). Both species exhibited lower daytime rubisco activation values when the plants were grown under $\mathrm{CO}_{2}$-enriched conditions (Table 1).

Measurement of rubisco activities from darksampled leaves of these plants, taken after sunset or before dawn, indicated that $\mathrm{CO}_{2}$-enrichment may affect the metabolism of carboxyarabinitol 1- phosphate (CA1P), an endogenous inhibitor of rubisco which occurs in both rice and soybean. In rice during the transition from day to night, rubisco activity declined more rapidly when the plants were growing in the $\mathrm{CO}_{2}$-enriched conditions (data not shown). This suggested that synthesis of CA1P was enhanced by the higher $\mathrm{CO}_{2}$. Growth temperature had little effect on this response. In contrast, with soybean this apparent enhancement of CAIP synthesis was more dependent upon elevated temperature than $\left[\mathrm{CO}_{2}\right]$.
These experiments with similarly-treated rice and soybean plants, indicate we must expect species-specific differences in the acclimation and regulation of rubisco among plants exposed to elevated $\left[\mathrm{CO}_{2}\right]$.

\section{Feedback effects from carbohydrate metabolism}

The most often cited explanation for acclimation and the down-regulation of rubisco is that $\mathrm{CO}_{2}$ enrichment causes an imbalance in the source-sink capacities, especially insufficient sink capacity for the excess carbohydrate production (Arp 1991, Farrar and Williams 1991, Stitt 1991, Sheen 1994, Woodrow 1994). The mechanism by which the imbalance is sensed probably involves feedback effects via end-product accumulation (Stitt 1991, Sheen 1994). This is indicated by a number of sugar-feeding studies which resulted in reduced photosynthesis, rubisco activity and concentration. Similarly, the over-expression of acid invertase in transgenic plants, and the resultant hexose accumulation, decreased photosynthesis and PCR cycle enzyme activities (Stitt et al. 1990, Sheen 1994).

A molecular model invokes the metabolite regulation of gene expression, with glucose providing a regulatory signal to repress the transcription of photosynthetic genes, including those encoding the small and large subunits of rubisco (Stitt 1991, Krapp et al. 1993, Sheen 1994). Nuclear genes encoding chloroplast proteins are reported to be more sensitive than chloroplastic genes when plants are exposed to elevated $\left[\mathrm{CO}_{2}\right]$ or sugar supply (Van Oosten et al. 1994). In addition, genes involved directly with carbohydrate metabolism can be positively, or negatively, regulated by sugars (Sheen 1994). This could be a means to up-regulate enzymes that process carbohydrate, and thereby assist in balancing the sink capacity with the source.

This concept is consistent with our findings 


\section{AGRICULTURAL AND FOOD SCIENCE IN FINLAND}

\section{Bowes, G. et al.: Metabolic regulation under high $\mathrm{CO}_{2}$ and temperature}

Table 2. Sucrose phosphate synthase (SPS) activity, sucrose and starch contents in rice grown for 48 days with natural sunlight and five different day/night temperatures and two $\left[\mathrm{CO}_{2}\right]$ regimes. The SPS activity was measured at $30^{\circ} \mathrm{C}$ under saturating substrate conditions using leaves frozen in liquid $\mathrm{N}_{2}$ at midday. Sucrose and starch contents represent peak daytime values sampled late in the afternoon.

\begin{tabular}{|c|c|c|c|c|}
\hline \multicolumn{2}{|c|}{ Growth Conditions } & \multirow{2}{*}{$\begin{array}{c}\text { SPS } \\
\text { Activity } \\
\left(\text { nmol } \mathrm{mg}^{-1}\right. \\
\left.\text { protein } \mathrm{h}^{-1}\right)\end{array}$} & \multirow{2}{*}{$\begin{array}{l}\text { Sucrose } \\
\text { Content } \\
\left(\mathrm{mg} \mathrm{g}^{-1}\right. \\
\text { dry wt) }\end{array}$} & \multirow{2}{*}{$\begin{array}{r}\text { Starch } \\
\text { Content }\end{array}$} \\
\hline $\begin{array}{l}\text { Temperature } \\
\left({ }^{\circ} \mathrm{C}\right)\end{array}$ & $\begin{array}{l}{\left[\mathrm{CO}_{2}\right]} \\
\left(\mu \mathrm{mol} \mathrm{mol}{ }^{-1}\right)\end{array}$ & & & \\
\hline $25 / 18$ & 660 & 1488 & 61.8 & 55.4 \\
\hline \multirow[t]{2}{*}{$28 / 21$} & 330 & 1440 & 52.2 & 42.4 \\
\hline & 660 & 1638 & 65.6 & 62.5 \\
\hline $31 / 24$ & 660 & 1728 & 60.5 & 34.2 \\
\hline $34 / 27$ & 660 & 1806 & 58.9 & 30.6 \\
\hline $37 / 27$ & 660 & 1620 & 50.6 & 21.3 \\
\hline
\end{tabular}

for $\mathrm{CO}_{2}$-enriched rice. While rubisco concentration and activation were down-regulated (Rowland-Bamford et al. 1991), the activity of sucrose phosphate synthase (SPS) was increased by about $20 \%$ at $600 \mathrm{vpm}$ as compared to $330 \mathrm{vpm}$ $\mathrm{CO}_{2}$ (Table 2). This enzyme is a key regulatory point in carbohydrate synthesis, especially for species which accumulate sucrose. The data shown in Table 2 are for SPS activity measured under saturating substrate and activator conditions as described by Stitt et al. (1988), using the resorcinol method to determine sucrose phosphate formation. Along with SPS activity, both sucrose and starch were increased by $\mathrm{CO}_{2}$-enrichment (Table 2). Rice clearly accumulates sucrose, as under all growth conditions the sucrose content of the leaves was equal to or higher than that of starch. In this it differs from soybean, which mainly accumulates starch.

A similar situation occurred in the sink-limited regions of transgenic tobacco leaves which had invertase over-expressed in the cell walls; rubisco and fructose bisphosphatase activities declined, but SPS increased (Stitt et al. 1990). More work is required to determine how $\mathrm{CO}_{2}$ enrichment influences the enzymes and allocation of carbohydrates in plants that are predominantly starch- or sucrose-accumulators. It is possible that plants exemplified by soybean have inherent capacity to handle the additional carbohydrate, and thus show less propensity for down-regulation of rubisco. Although soybean accumulates substantially more starch under $\mathrm{CO}_{2}$ - enriched conditions, we have not observed any major up-regulation of ADP-glucose pyrophosphorylase comparable to that of SPS activity in rice.

\section{$\mathrm{CO}_{2}$ enrichment and temperature effects}

Environmental conditions have a marked influence on the stimulation of photosynthesis and growth by $\mathrm{CO}_{2}$-enrichment. Because of the efficiency effect, $\mathrm{CO}_{2}$-enrichment can improve resource use, even when parameters such as temperature are exerting stress (Gifford 1992, Bowes 1993). Higher global temperatures are an important consideration in the rising $\mathrm{CO}_{2}$ debate because of interactive effects on photosynthesis. A rise in temperature lowers the ratio of $\left[\mathrm{CO}_{2}\right] /$ $\left[\mathrm{O}_{2}\right]$ in solution, shifts the specificity of rubisco towards oxygenase, enhances photorespiration and dark respiration, and increases the sink response relative to the source. Thus, positive effects of $\mathrm{CO}_{2}$-enrichment are potentially greater as the temperature rises. Long (1991) calculated that with no down-regulation of rubisco an increase in atmospheric $\mathrm{CO}_{2}$ to $650 \mu \mathrm{mol} \mathrm{mol}^{-1}$ could increase light-saturated assimilation by $20 \%$ at $10^{\circ} \mathrm{C}$ but $105 \%$ at $35^{\circ} \mathrm{C}$, and raise the temperature optimum for photosynthesis by $5^{\circ} \mathrm{C}$.

Interactive effects of elevated $\left[\mathrm{CO}_{2}\right]$ and temperature on photosynthesis are demonstrated experimentally in Table 1. For rice, the difference in photosynthetic rate between the ambient and twice-ambient $\left[\mathrm{CO}_{2}\right]$ treatment was about $60 \%$ at all growth temperatures. However, with soybean the difference increased with growth temperature, being $49 \%$ at $32^{\circ} \mathrm{C}$ but $95 \%$ at $40^{\circ} \mathrm{C}$ (Table 1). In both species, the adverse effects of elevated temperature on photosynthesis were 


\section{AGRICULTURAL AND FOOD SCIENCE IN FINLAND}

\section{Vol. 5 (1996): 261-270.}

moderated by $\mathrm{CO}_{2}$ enrichment, but the soybean response was closer to the Long model.

Photosynthetic gains may not always be realized in long-term growth and yield due to an interplay of factors that complicate the issue. For example, leaves compensate for increased air temperatures by greater transpiration; whereas $\mathrm{CO}_{2}$ enrichment tends to raise foliar temperatures by reducing transpiration (Allen 1990, Campbell et al. 1990, Long 1991). Furthermore, species within just the $\mathrm{C}_{3}$ category differ markedly in the temperature regimes to which they are adapted, and in tolerance of the low and high extremes where temperature becomes stressful. Temperature regimes that enhance $\mathrm{CO}_{2}$-stimulated vegetative growth can negatively impact reproductive growth. The grain yield of $\mathrm{CO}_{2}$-enriched rice showed about a $10 \%$ decline for each $1^{\circ} \mathrm{C}$ rise above $26^{\circ} \mathrm{C}$, and similar scenarios have been reported for soybean and wheat (Baker et al. 1989, 1992, Mitchell et al. 1993). This is because growth and reproduction reflect the integrated temperature response of metabolism and developmental processes. As a consequence, species, developmental stage, light regime, nutrient status, and the temperature range, all modify temperature $\mathrm{x} \mathrm{CO}_{2}$ responses (Rawson 1992).

In rice and soybean there was an interplay between elevated growth temperatures and $\left[\mathrm{CO}_{2}\right]$ on rubisco parameters (Table 1). For both species, rubisco protein concentration declined with increasing temperature, as well as with elevated $\left[\mathrm{CO}_{2}\right]$. Similarly, the activation of rubisco from both species declined with higher temperatures and $\left[\mathrm{CO}_{2}\right]$. Rice and soybean differed in terms of the response of rubisco's catalytic turnover rate. For rice there was no effect of temperature or $\left[\mathrm{CO}_{2}\right]$. In contrast, the $\mathrm{K}_{\text {cat }}$ for soybean rubisco was increased by both elevated temperature and $\left[\mathrm{CO}_{2}\right]$ (Table 1). Despite the down-regulation in rubisco concentration and activation, the substrate effect from $\mathrm{CO}_{2}$-enrichment maintained relatively high leaf photosynthetic rates at unfavorably high temperatures (Table 1).

In addition to effects on photosynthetic and rubisco activity, elevated temperatures influence carbohydrate metabolism. In $\mathrm{CO}_{2}$-enriched rice plants, SPS activity was increased by temperatures up to $34^{\circ} \mathrm{C}$, but thereafter declined (Table 2). Total non-structural carbohydrates declined with increasing growth temperature, but the decline in starch content was much greater than for sucrose (Table 2). Consequently, the sucrose to starch ratio increased with temperature. This was opposite to the effect of $\mathrm{CO}_{2}$ enrichment, which tended to decrease the ratio.

We have found that although $\mathrm{CO}_{2}$-enriched soybeans synthesized more starch, ADP-glucose pyrophosphorylase activity was not greatly altered by temperature or $\left[\mathrm{CO}_{2}\right]$. However, high temperature $\left(40^{\circ} \mathrm{C}\right)$ caused a dramatic fall-out of starch branching enzyme (Q-enzyme) activity, which was ameliorated by $\mathrm{CO}_{2}$-enrichment (Pennanen et al. 1995).

These data with rice and soybean suggest that high temperatures not only influence the amount of carbohydrate produced, but also its composition, possibly shifting the amylose-to-amylopectin ratio in favor of the former. However, $\mathrm{CO}_{2}-$ enrichment moderates the differences, and can have positive effects in a stress situation.

Future increases in atmospheric $\mathrm{CO}_{2}$ and day temperatures have the potential for positive interactive effects with many $\mathrm{C}_{3}$ species, though in some regions the photosynthetic gains may not translate into greater yields, because of temperature stress on reproductive processes (Allen 1990, Bowes 1993). If mean global night temperatures increase the outcome is less predictable. Higher temperatures at night could negate the lower respiration of $\mathrm{CO}_{2}$-enriched species (Amthor et al. 1992), and increase damage to the reproductive system (Ahmed et al. 1993); but in heat-tolerant plants it may improve carbohydrate mobilization and ease sink limitations on photosynthesis (Ahmed et al. 1993).

In summary, among $\mathrm{C}_{3}$ species the response to $\mathrm{CO}_{2}$ enrichment is variable. Restrictive growth conditions can be influential, but evidence also points to the existence of inherent interspecific and intraspecific differences, reflective of different RuBP regeneration and sink capacities. Limitations in these capacities can lower the increases that might otherwise be anticipated from 


\section{AGRICULTURAL AND FOOD SCIENCE IN FINLAND}

Bowes, G. et al.: Metabolic regulation under high $\mathrm{CO}_{2}$ and temperature

rubisco kinetics alone. There is evidence that the rise in $\left[\mathrm{CO}_{2}\right]$ could offset the negative effects of high temperature regimes on photosynthesis and growth.
Acknowledgements. Work in my laboratory was supported by the USDA/SEA NRICG Photosynthesis and Respiration Program, Grant No. 93-37306-9386 (GB), USDOE Grant No. DE-AI05-88ER69014 (LHA Jr), and Finnish Academy of Science Grant No. 1022668 (AHP).

\section{References}

Ahmed, F.E., Hall, A.E. \& Madore, M.A. 1993. Interactive effects of high temperature and elevated carbon dioxide concentration on cowpea [Vigna unguiculata (L.) Walp.]. Plant, Cell \& Environment 16: 835-842.

Allen, L.H., Jr. 1990. Plant responses to rising carbon dioxide and potential interactions with air pollutants. Journal of Environmental Quality 19: 15-34.

Amthor, J.S., Koch, G.W. \& Bloom, A.J. 1992. CO inhibits respiration in leaves of Rumex crispus L. Plant Physiology 98: 757-760.

Arp, W.J. 1991. Effects of source-sink relations on photosynthetic acclimation to $\mathrm{CO}_{2}$. Plant, Cell \& Environment 14: 869-875.

Badger, M.R. 1992. Manipulating agricultural plants for a future high $\mathrm{CO}_{2}$ environment. Australian Journal of Botany 40: 421-429.

Baker, J.T., Allen, L.H., Jr., Boote, K.J., Jones, P. \& Jones, J.W. 1989. Response of soybean to air temperature and carbon dioxide concentration. Crop Science 29: 98-105.

-, Allen, L.H., Jr. \& Boote, K.J. 1992. Temperature effects on rice at elevated $\mathrm{CO}_{2}$ concentration. Journal of Experimental Botany 43: 959-964.

-, Allen, L.H., Jr., Boote, K.J., Jones, P. \& Jones, J.W. 1990. Rice photosynthesis and evapotranspiration in subambient, ambient, and superambient carbon dioxide concentrations. Agronomy Journal 82: 834-840.

Berner, R.A. 1993. Paleozoic atmospheric $\mathrm{CO}_{2}$ : importance of solar radiation and plant evolution. Science 261 : 68-70.

Besford, R.T., Ludwig, L.J. \& Withers, A.C. 1990. The greenhouse effect: acclimation of tomato plants growing in high $\mathrm{CO}_{2}$, photosynthesis and ribulose-1, 5-bisphosphate carboxylase protein. Journal of Experimental Botany 41: 925-931.

Böger, P. 1980. The $\mathrm{O}_{2} / \mathrm{CO}_{2}$ cycle: development and atmospheric consequences. In: San Pietro, A. (ed.). Biochemical and Photosynthetic Aspects of Energy Production. Academic Press, New York. p. 175-190.

Bowes, G. 1991. Growth at elevated $\mathrm{CO}_{2}$ : photosynthetic responses mediated through Rubisco. Plant, Cell \& Environment 14: 795-806.

- 1993. Facing the inevitable: plants and increasing atmospheric $\mathrm{CO}_{2}$. Annual Review of Plant Physiology and Plant Molecular Biology 44: 309-332.

Budyko, M.I., Ronov, A.B. \& Yanshin, A.L. 1987. History of the Earth's Atmosphere. Springer-Verlag, New York. 139 p.

Campbell, W.J., Allen, L.H., Jr. \& Bowes, G. 1988. Effects of $\mathrm{CO}_{2}$ concentration on rubisco activity, amount, and photosynthesis in soybean leaves. Plant Physiology 88: 1310-1316.

-, Allen, L.H., Jr. \& Bowes, G. 1990. Response of soybean canopy photosynthesis to $\mathrm{CO}_{2}$ concentration, light, and temperature. Journal of Experimental Botany 41: 427-433.

Carter, T.R. 1996. Developing scenarios of atmosphere, weather and climate for northern regions. Agricultural and Food Science in Finland 5: 235-249. (this issue)

Conroy, J. \& Hocking, P. 1993. Nitrogen nutrition of $\mathrm{C}_{3}$ plants at elevated atmospheric $\mathrm{CO}_{2}$ concentrations. Physiologia Plantarum 89: 570-576.

Dansgaard, W., Johnsen, S.J., Clausen, H.B., DahlJensen, D., Gundestrup, N.S., Hammer, C.U., Hvidberg, C.S., Steffensen, J.P., Sveinbjornsdottir, A.E., Jouzel, J. \& Bond, G. 1993. Evidence for general instability of past climate from a $250-\mathrm{kyr}$ ice-core record. Nature 364: 218-220.

Farquhar, G.D., Caemmerer, S. von \& Berry, J.A. 1980. A biochemical model of photosynthetic $\mathrm{CO}_{2}$ assimilation in leaves of $\mathrm{C}_{3}$ species. Planta 149: 78-90

Farrar, J.F. \& Williams, M.L. 1991. The effects of increased atmospheric carbon dioxide and temperature on carbon partitioning, source-sink relations and respiration. Plant, Cell \& Environment 14: 819-830.

Gifford, R.M. 1992. Interaction of carbon dioxide with growth-limiting environmental factors in vegetation productivity: implications for the global carbon cycle. In: Stanhill, G. (ed.). Advances in Bioclimatology, Volume 1. Springer Verlag, New York. p.24-58.

King, A.W., Emanuel, W.R. \& Post, W.M. 1992. Projecting future concentrations of atmospheric $\mathrm{CO}_{2}$ with global carbon cycle models: the importance of simulating historical changes. Environmental Management 16: 91-108.

Krapp, A., Hofmann, B., Schaefer, C. \& Stitt, M. 1993 Regulation of the expression of $r b c S$ and other photosynthetic genes by carbohydrates: a mechanism for the 'sink regulation' of photosynthesis? Plant Journal 3: 817828.

Long, S.P. 1991. Modification of the response of photosynthetic productivity to rising temperature by atmospheric $\mathrm{CO}_{2}$ concentrations: Has its importance been underestimated? Plant, Cell \& Environment 14: 729-739.

-, Baker, N.R. \& Raines, C.A. 1993. Analysing the responses of photosynthetic $\mathrm{CO}_{2}$ assimilation to long-term elevation of atmospheric $\mathrm{CO}_{2}$. Vegetatio 104/105: 3345.

Mitchell, R.A.C., Mitchell, V.J., Driscoll, S.P., Franklin, J. \& Lawlor, D.W. 1993. Effects of increased $\mathrm{CO}_{2}$ 
Vol. 5 (1996): 261-270.

concentration and temperature on growth and yield of winter wheat at two levels of nitrogen application. Plant, Cell \& Environment 16: 521-529.

Pennanen, A.H., Vu, J.C.V., Allen, L.H., Jr. \& Bowes, G. 1995. Elevated $\mathrm{CO}_{2}$ and temperature effects on enzymes of sucrose and starch synthesis in soybean. Plant Physiology 108: 90.

Pettersson, R. \& McDonald, A.J.S. 1994. Effects of nitrogen supply on acclimation of photosynthesis to elevated $\mathrm{CO}_{2}$. Photosynthesis Research 39: 389-400.

Post, W.M., Peng, T.-H., Emanuel, W.R., King, A.W., Dale, V.H. \& DeAngelis, D.L. 1990. The global carbon cycle. American Scientist 78: 310-326.

Rawson, H.M. 1992. Plant responses to temperature under conditions of elevated $\mathrm{CO}_{2}$. Australian Journal of Botany 40: 473-490.

Rowland-Bamford, A.J., Baker, J.T., Allen, L.H., Jr. \& Bowes, G. 1991. Acclimation of rice to changing atmospheric carbon dioxide concentration. Plant, Cell \& Environment 14: 577-583.

Sage, R.F. 1994. Acclimation of photosynthesis to increasing atmospheric $\mathrm{CO}_{2}$ : the gas exchange perspective. Photosynthesis Research 39: 351-368.

-, Sharkey, T.D. \& Seemann, J.R. 1989. Acclimation of photosynthesis to elevated $\mathrm{CO}_{2}$ in five $\mathrm{C}_{3}$ species. Plant Physiology 89: 590-596.

Sharkey, T.D. \& Vanderveer, P.J. 1989. Stromal phosphate concentration is low during feedback limited photosynthesis. Plant Physiology 91: 679-684.

Sheen, J. 1994. Feedback control of gene expression. Photosynthesis Research 39: 427-438.

Socias, F.X., Medrano, H. \& Sharkey, T.D. 1993. Feedback limitation of photosynthesis of Phaseolus vulgaris L. grown in elevated $\mathrm{CO}_{2}$. Plant, Cell \& Environment 16: 81-86.

Spencer, W. \& Bowes, G. 1986. Photosynthesis and growth of water hyacinth under $\mathrm{CO}_{2}$ enrichment. Plant Physiology 82: 528-533.

Stitt, M. 1991. Rising $\mathrm{CO}_{2}$ levels and their potential significance for carbon flow in photosynthetic cells. Plant, Cell \& Environment 14: 741-762.

-, Schaewen, A. von \& Willmitzer, L. 1990. "Sink" regulation of photosynthetic metabolism in transgenic tobacco plants expressing yeast invertase in their cell wall in- volves a decrease of the Calvin-cycle enzymes and an increase of glycolytic enzymes. Planta 183: 40-50.

- \& Schulze, D. 1994. Does Rubisco control the rate of photosynthesis and plant growth? An exercise in molecular ecophysiology. Plant, Cell \& Environment 17: 465487.

-, Wilke, I., Fiel, R. \& Heldt H.W. 1988. Coarse control of sucrose phosphate synthase in leaves: alterations of kinetic properties in response to the rate of photosynthesis and the accumulation of sucrose. Planta 174: 217230.

Takahashi, T., Tans, P. \& Fung, I. 1992. Balancing the budget. Carbon dioxide sources and sinks, and the effects of industry. Oceanus 35: 18-28.

Thomson, K.S. 1993. Northern exposures. American Scientist 81: 522-525.

Tissue, D.T., Thomas, R.B. \& Strain, B.R. 1993. Longterm effects of elevated $\mathrm{CO}_{2}$ and nutrients on photosynthesis and rubisco in loblolly pine seedlings. Plant, Cell \& Environment 16: 859-865.

Van Oosten, J.J., Wilkins, D. \& Besford, R.T. 1994. Regulation of the expression of photosynthetic nuclear genes by high $\mathrm{CO}_{2}$ is mimicked by carbohydrates: a mechanism for the acclimation of photosynthesis to high $\mathrm{CO}_{2}$ ? Plant, Cell \& Environment 17: 913-923.

Vu, J.C.V., Allen, L.H., Jr. \& Bowes, G. 1987. Drought stress and elevated $\mathrm{CO}_{2}$ effects on soybean ribulose bisphosphate carboxylase activity and canopy photosynthetic rates. Plant Physiology 83: 573-578.

- \& Yelenosky, G. 1988. Water deficit and associated changes in some photosynthetic parameters in leaves of 'Valencia' orange (Citrus sinensis (L.) Osbeck). Plant Physiology 88: 375-378.

Woodrow, I.E. 1994. Optimal acclimation of the $C_{3}$ photosynthetic system under enhanced $\mathrm{CO}_{2}$. Photosynthesis Research 39: 401-412.

Yapp, C.J. \& Poths, H. 1992. Ancient atmospheric $\mathrm{CO}_{2}$ pressures inferred from natural geothites. Nature $355^{2}$ : 342-344.

Yelle, S., Beeson, R.C., Jr., Trudel, M.J. \& Gosselin, A. 1989. Acclimation of two tomato species to high atmospheric $\mathrm{CO}_{2}$. II. Ribulose-1,5-bisphosphate carboxylase/oxygenase and phosphoenolpyruvate carboxylase. Plant Physiology 90: 1473-1477. 
Bowes, G. et al.: Metabolic regulation under high $\mathrm{CO}_{2}$ and temperature

\title{
SELOSTUS
}

\section{Hiilihydraatti- ja proteiiniaineenvaihdunnan säätely kohonneen hiilidioksidipitoisuuden ja lämpötilan vallitessa}

\author{
George Bowes, Joseph C.V. Vu, Mian W. Hussain, Arja H. Pennanen ja L. Hartwell Allen, Jr. \\ University of Florida, USA ja Helsingin yliopisto
}

Ilmakehän nykyinen $\mathrm{CO}_{2}$-pitoisuus ei kyllästä $\mathrm{C}_{3}$-fotosynteesiä, joten fotosynteesi tehostuu $\mathrm{CO}_{2}-$ pitoisuuden kaksinkertaistumisen seurauksena. Tehostuminen ei kuitenkaan ole aina yhtä voimakasta. Kasvin mukautuminen korkeaan $\mathrm{CO}_{2}$-pitoisuuteen kasvun aikana voi hidastaa fotosynteesiä, jotta hiilen saanti ja hyödyntäminen olisivat optimaalisia. Päätekijä mukautumisessa on rubiscon väheneminen. Rubisco on entsyymi, joka liittää hiilidioksidia sokerifosfaattiin Calvinin kierrossa. Kasvien aineenvaihduntaa korkeassa $\mathrm{CO}_{2}$-pitoisuudessa ja lämpötilassa tutkittiin riisillä ja soijapavulla. Riisin fotosynteesi ja kasvu olivat huipussaan 500 ppm:n ja soijapavulla 990 ppm:n $\mathrm{CO}_{2}$-pitoisuudessa. Rubiscon pitoisuus vähe- ni $\mathrm{CO}_{2}$-pitoisuuden ja lämpötilan noustessa etenkin riisillä. $\mathrm{CO}_{2}$-pitoisuuden tai lämpötilan nousu eivät vaikuttaneet rubiscon aktiivisuuteen riisillä, mutta soijapavulla vaikutus havaittiin. Riisin kykyä käsitellä hiilihydraattia mitattiin sakkaroosifosfaattisyntaasin aktiivisuudella, joka nousi $\mathrm{CO}_{2}$-pitoisuuden myötä, mutta ei muuttunut lämpötilan kohotessa. $\mathrm{CO}_{2}$-pitoisuuden nousu lisäsi lehtien hiilihydraattipitoisuutta, mutta korkeampi lämpötila vähensi etenkin tärkkelyksen osuutta. Vaikka $\mathrm{C}_{3}$-lajit reagoivat hiilidioksidiin ja lämpötilaan eri tavoin, $\mathrm{CO}_{2}$-pitoisuuden nousu voi lieventää äärilämpötiloista johtuvia epäsuotuisia reaktioita. 